\title{
Kadınların Kişilik Özelliklerinin Travmatik Doğum Algısına Etkisi
}

\author{
Büşra YILMAZ ${ }^{1}$, (iD İlayda SEL², (iD Nevin ŞAHİN ${ }^{3}$
}

'Araştırma Görevlisi, İstanbul Üniversitesi Cerrahpaşa Florence Nightingale Hemşirelik Fakültesi, İstanbul, Türkiye. ${ }^{2}$ Hemşire, Sağlık Bilimleri Üniversitesi Bakırköy Dr. Sadi Konuk Eğitim ve Araştırma Hastanesi, İstanbul. Türkiye. ${ }^{3}$ Prof. Dr., İstanbul Üniversitesi Cerrahpaşa Florence Nightingale Hemşirelik Fakültesi, İstanbul, Türkiye.

$\ddot{O} z$

Giriş: Kadın yaşamında eşsiz bir deneyim olan doğum genellikle olumlu bir olay olarak algılanmaktadır. Amaç: Bu çalışma 18-65 yaş arasındaki kadınların kişilik özelliklerinin travmatik doğum algısına etkisini belirlemek amacıyla yapıldı. Yöntem: Kesitsel tanımlayıcı ve ilişki arayıcı tipteki çalışmanın evrenini Türkiye'de yaşayan 18-65 yaş aralığındaki kadınlar, örneklemini ise İstanbul'da yaşayan, Türkçe dilini okuyup anlayabilen ve çalışmaya katılımda gönüllü 300 kadın oluşturdu. Veri toplama aracı olarak "Katılımcı Tanıtım Formu", "Cervantes Kişilik Ölçeği (CKÖ)" ve "Travmatik Doğum Algısı Ölçeği (TDAÖ)” kullanıldı. Verilerin değerlendirilmesinde tanımlayıcı istatistikler, Tek Yönlü ANOVA testi, bağımsız örneklem t testi, Spearman korelasyon testleri ve çoklu regresyon analizinden yararlanıldı. Bulgular: Çalışmada katılımcıların \%17.3'ünün olumsuz doğum deneyimi varken, \%77'si başkalarından olumsuz doğum hikayeleri dinlemişti. Olumsuz doğum deneyimi olduğunu ifade eden kadınlar diğerlerine göre daha dışa dönük kişilik özelliğine sahipti. Çalışmada TDAÖ toplam puanı $64.57 \pm$ 31.48 idi. CKÖ alt boyut puanları; dişa/içe dönük olma $17.06 \pm 3.51$, duygusal denge $17.27 \pm 5.51$ ve tutarlı/tutarsız olma $17.00 \pm 4.33$ bulundu. Kişilik ölçeği alt boyutlarından duygusal denge alt boyutu ile tutarlı/tutarsız olma alt boyutu arasında pozitif yönde zayıf derecede anlamlı bir ilişki olduğu belirlendi. Bu analize göre CKÖ alt boyutlarından “duygusal denge” alt boyutundaki toplam \%38.6'l1k değişim, travmatik doğum algısı düzeyini artırmada etkili bulundu. Sonuç: Kadının kişilik özellikleri travmatik doğum algısını etkilemektedir. Travmatik doğum algısı yüksek olan kadınların kişilik özelliklerinin incelenmesi ve elde edilen sonuçların bakım ve tedavi süreçlerinde dikkate alınması önerilmektedir. Anahtar Kelimeler: Doğum, Kadın, Kişilik Özellikleri, Travmatik.

\footnotetext{
Abstract
The Effect of Women's Personality Traits on Traumatic Birth Perception
Backround: Birth is a unique experience, women are often perceived as a positive life event. Objectives: This study was conducted to
determine the effect of personality traits on the perception.of traumatic birth in women between the ages of 18-65. Methods: This cross-
sectional descriptive and relational study the universe of living in Turkey, women in 18-65 age, the sample of living in Istanbul, can read and
understand Turkish created voluntary participation of 300 women in the study. "Participant introduction form", "Cervantes Personality Scale
(CPS)" and "Traumatic Birth Perception Scale (TBPS)" were used as data collection tools. Descriptive statistics, One-Way ANOVA test,
independent sample t test, Spearman correlation tests and multiple regression analysis were used to evaluate the data. Results: While $17.3 \%$
of the participants in the study had negative birth experience, $77 \%$ listened to negative birth stories from others. Women who stated that they
had negative birth experiences had more extroverted personality traits than others. The total score of TBPS in the study was $64.57 \pm 31.48$.
CPS subscale scores; extraversion/introversion was $17.06 \pm 3.51$, emotional balance was $17.27 \pm 5.51$, and consistency/inconsistency was
17.00 \pm 4.33. It was determined that there is weakly significant positive relationship between the emotional balance
simension of the personality scale and the consistency/inconsistency sub-dimension. According to this analysis, total of $38.6 \%$ change in the
"emotional balance" sub-dimension of the CPS sub-dimensions was found to be effective in increasingthe level of traumatic birth perception.
Conclusion: Women's personality traits affect the perception traumatic birth. It is recommended to examine personality traits of women with
high perception of traumatic birth and consider results obtained in care and treatment processes.
Keywords: Birth, Female, Personality Traits, Traumatic.
}

Geliş Tarihi / Received: 20.02.2021 Kabul Tarihi / Accepted: 21.09.2021

Correspondence Author: Hemşire, Sağlık Bilimleri Üniversitesi Bakırköy Dr. Sadi Konuk Eğitim ve Araştırma Hastanesi, İstanbul, Türkiye. E-posta: ilayda.sel@outlook.com

Cite This Article: : Yılmaz B, Sel İ, Şahin N. Kadınların Kişilik Özelliklerinin Travmatik Doğum Algısına Etkisi. Dokuz Eylül Üniversitesi Hemşirelik Fakültesi Elektronik Dergisi. 2021; 14(4): 423-432 
$\mathbf{K}$ adın yaşamında eşsiz bir deneyim olan doğum genellikle olumlu bir olay olarak algılanmaktadır. Ancak doğumun psikolojik uyum için kritik bir süreç olduğu ve ruh sağlı̆̆ sorunlarının gelişimini hızlandırabileceği de kabul edilmektedir (1). Kadınların çoğu doğumu, başarıyı hissettiren bir yaşam geçişi olarak kabul ederken, bazıları ise çok zor, stresli, yorucu ve önceden tahmin edilemez travmatik bir deneyim olarak algılayabilmektedir (2). Travmatik doğum, bir kadının doğurganlığını bebeği ve kendisi için bir yaralanma veya ölüm tehdidi olarak algılamasıdır. Travmatik doğum kadını, bebeğini ve ailesini olumsuz etkilemektedir (3). Travmatik doğum deneyimleyen kadınlar, olayı sıkça hatırlama, olayla ilgili kabus görme ve olayı yeniden yaşama gibi travma sonrası stres belirtileri sergileyebilmektedir (4). Travmatik doğum orta düzey kuramında ise travmatik doğumun özellikleri optimal bakımdan yoksun olma, değer görmeme, korkunç kontrol kaybı, ihmal edilen iletişim ve göz ardı edilmiş olma olarak sıralanmıştır (5).

Son yıllarda, doğumu tıbbileştirme eğiliminde olan müdahaleli doğum uygulamalarında önemli bir artış görülmektedir. Bu prosedürler kadınların doğum yapma yeteneğini zayıflatabilmekte ve doğum deneyimini olumsuz yönde etkilemektedir (6). Gebelerin travayda hareket özgürlüğünün kısıtlanması, rutin epizyotomi ve indüksiyon uygulamaları, doğumların travmatik bir olay olarak algılanmasına neden olabilmektedir (4). Kadınlarda travmatik doğum algısı değerlendirilmez ve tedavi edilmezse; aile ilişkilerine zarar verebilir, anne sütünü azaltabilir ve uzun vadede çocuklarında duygusal, bilişsel ve davranışsal bozukluklara neden olabilir (7). Travmatik doğum prevalansının $\% 10$ ile \%34 arasında olduğu bildirilirken (8), bazı çalışmalarda kadınların yarısından fazlasının doğumlarını travmatik bir deneyim olarak tanımladığı bildirilmektedir (9). Travmatik doğum deneyimi olan kadınlarda travma sonrası stres bozukluğu sendromu görülme sıklığ $\% 3.1$ ile \%15.7 arasında değişmektedir (10). Kürtaj öyküsü, multiparite, cinsel istismar öyküsü, korunmasız cinsel ilişki, geçmişteki olumsuz doğum deneyimleri veya menstruasyonla ilgili sorunlar travmatik doğum algısını artırabilmektedir (8). Bunların yanı sıra kadınların kişilik özellikleri ve kültürel değerleri de travmatik doğum algısını etkileyebilmektedir. Kadınların doğum sürecine ilişkin algıları, doğum olayını anlamlandırmaları birbirinden farklı olabilmektedir. Olumsuz ya da zor geçen bir doğum anı bazı kadınlar tarafından travmatik olarak tanımlanırken, bazı kadınlar için bu durum normal olarak algılanabilmektedir (11). Beklentisinden farklı, travmatik doğum deneyimleyen kadınlardan bazıları ise bebeğini sağlıklı bir şekilde kucağına aldığında, tüm bu deneyimi olumlu bir sonuç olarak algılayabilmektedir (7). Doğuma yönelik algıdaki çeşitlilik, kadının kişilik özellikleri ve yaşadığı toplumun doğum eylemine yüklediği anlamdan kaynaklanabilmektedir. Ebeveynliğe geçişte önemli rol oynayan kişilik özellikleri doğum algısını da etkilemektedir. Kişilik, bireyin davranış ve düşüncelerini belirleyen, hayatını düzenleyen dinamik bir organizasyondur. Kişilik özellikleri, tanımlanabilir nitelikte olup sürekli değişen ve gelişen bir sistem olarak tanımlanmaktadır (12). Kişilik özelliklerinden, özellikle nevrotik ve dışa dönük kişilik yapısı, sağlık sonuçlarıyla ilişkili olduğu bildirilmiştir. Örneğin, nevrotik kişilik özellikleri, kronik stres, sosyal fobi, artan depresyon riski ve anksiyete ile ilişkili bozukluklara yatkınlığı artırırken, dışa dönüklük kişilik özellikleri depresyon ve sosyal fobiye karşı koruyucu özellik göstermektedir $(13,14)$. Kadınların kişilik özellikleri, doğuma yönelik algılarını etkilemektedir. Kişilik özellikleri açısından incelendiğinde, özellikle kırılgan, nevrotik, depresif ve kaygılı özellik gösteren kadınların doğumu travmatik bir olgu olarak algılama eğiliminde oldukları bulunmuştur (15).

Beck travmatik doğum orta düzey kuramında travma algısının "bakanın gözünde" olduğunu belirtmiş ve travmatik algıyı deneyimleyen kadının tanılanmasının gerekliliğini savunmuştur. Ayrıca kuramda "Tek bir çakıl taşı suya düştüğünde dalgaların yayılması gibi, bireylerin davranışları da geniş kapsamlı etkilere sahip olabilir" ifadesi ile ileriki süreçlerde anne-bebek etkileşiminin bebeğin bilişsel ve duygusal gelişimi üzerinde etkili olduğu üzerinde durulmuştur (5). Kadın sağlığın korunması ve geliştirilmesinde travmatik doğum algısı için risk faktörlerinin ve kadınların travmatik doğum deneyimlerinin belirlenmesi önemlidir (8). Bu çalışma, 18-65 yaş arasındaki kadınlarda kişilik özelliklerinin travmatik doğum algısına etkisini belirlemek amacıyla planlandı.

\section{Araștırma Soruları}

- 18-65 yaş aralığındaki kadınlarda kişilik özellikleri nasıldır?

- 18-65 yaş aralığındaki kadınlarda travmatik doğum algısı düzeyi nasıldır?

- 18-65 yaş aralığındaki kadınlarda kişilik özelliklerinin travmatik doğum algısına etkisi nedir?

\section{Araştırmanın Tipi}

\section{Yöntem}

Kesitsel tanımlayıcı ve ilişki arayıcı tasarımdaki bu çalışma Şubat-Haziran 2019 tarihleri arasında gerçekleştirildi.

\section{Araştırmanın Yapıldı̆̆ Yer}

İstanbul, Türkiye'nin birçok bölgesinden çok sayıda insanın göç ettiği ve farklı sosyodemografik özelliklere sahip insanların yaşadığı bir metropol kentidir. Kapladığı geniş alan ve barındırdığı yüksek nüfus nedeniyle araştırma verileri İstanbul'da toplandı. Evrenden örneklem seçimine gidilmeksizin İstanbul'un Taksim meydanında haftanın iki gününde bulunan kadınlar araştırmaya davet edildi. Araştırma verileri araştırmacılar tarafindan yüz yüze görüşme yöntemiyle topland1.

\section{Araştırmanın Evren ve Örneklemi}

Türkiye İstatistik Kurumu (2019) (16) verilerine göre Türkiye'de yaşayan 18-65 yaş arası kadın sayısı 24 milyon 790 bin 893 idi. Örneklem seçiminde; evreni bilinen örneklem hesaplama formülü (\%95 güven aralığı, \%5 hata payı, \%50 görülme sıklığı) kullanıldı. Hesaplama sonucuna göre örneklem büyüklüğü 385 olarak belirlendi. Belirtilen tarihler arasında 400 katılımcıyla görüşüldü fakat katılımcılardan 100'ü araştırmaya katılımda gönüllü olmadı. Araştırmaya toplam 300 kadın dâhil edildi. Araştırmaya 18-65 yaş aralığında olan, İstanbul'da ikamet eden, Türkçe okuyup anlayabilen kadınlar ve çalışmaya katılmak için gönüllü olanlar dâhil edildi. Dünya Sağlık Örgütü 18-65 yaş aralığındaki bireylerin genç erişkinler grubuna girdiğini bildirdiğinden araştırmaya bu yaş grubu dâhil edildi. 


\section{Veri Toplama Araçları}

Çalışmada sosyodemografik veriler yüz yüze görüşme yöntemiyle toplanırken, ölçekler katılımcının öz bildirimine dayalı kendi kendine cevaplama yöntemiyle doldurtuldu. Veriler "Katılımeı Tanıtım Formu", "Cervantes Kişilik Ölçeği” ve "Travmatik Doğum Algısı Ölçeğì" ile elde edilmiştir. Araştırma verileri araştırmacılar tarafindan yüz yüze görüşme yöntemiyle toplandı.

Katılımcı Tanitım Formu

Literatür doğrultusunda araştırmacılar tarafindan hazırlanan form toplam 15 maddeden oluşmaktadır. Formda sosyodemografik bilgiler ve katılımcının doğum deneyimiyle ilgili sorulara yer verilmiştir $(2,11,17)$.

Cervantes Kişilik Ölçeği (CKÖ)

20 maddelik ölçeğin Türkçe geçerlik ve güvenirlik çalışması Bal ve Şahin tarafından 2011 yılında yapılmıştır (17). Dışa/içe dönük olma (7 madde), duygusal denge (7 madde) ve tutarlı/tutarsız olma (6 madde) olmak üzere üç alt boyuttan oluşan ölçekte ters puanlanan madde bulunmamaktadır. Ölçek altılı likert tiptedir $(0=$ hiç uygun değil; $5=$ çok uygun). Ölçekte her alt grupta bireyin verdiği puan arttıkça içe dönük olma, duygusal açıdan dengesiz olma ve tutarsız olma özelliği artmaktadır. Benzer şekilde her alt grupta bireyin verdiği puan azaldıkça dışa dönük olma, duygusal açıdan dengeli olma ve tutarlı olma özelliği artmaktadır. Cronbach alpha katsayısı dışa/içe dönük olma, duygusal denge ve tutarlı/tutarsız olma alt boyutları için sırasıyla $.97, .81$ ve .71 'dir (17). Bu çalışmada ise Cronbach alfa değerleri sırasıyla $.89,76, .70$ olarak belirlenmiştir.

Travmatik Doğum Algısı Ölçeği (TDAÖ)

Yalnız ve ark. tarafindan 2016 yılında geliştirilen ölçek on birli likert tipte ve tek boyutludur (18). Ters puanlanacak maddesi olmayan ölçekte her öncül 0-10 arasında puanlanmaktadır. Ölçek puanı minimum 0 ve maksimum 130'dur. Ölçek toplam puanı 0-26 puan aralığı çok düşük, 27-52 puan aralı̆̆ı düşük, 53-78 puan aralığı orta, aralı̆̆ı 79-104 puan aralığı yüksek ve 105-130 puan aralığı çok yüksek travmatik doğum algısı düzeyidir. Ölçeğin Cronbach's alpha katsayıs1 .89'dur. Bu çalışmada ölçeğin Cronbach's alpha katsayısı .91 olarak belirlenmiştir.

\section{Verilerin Değerlendirilmesi}

Araştırmada elde edilen bulgular değerlendirilirken IBM SPSS Statistics 22 (IBM SPSS, Türkiye) programı kullanıldı. Değişkenlerin normal dağllıma uygunluğu Shapiro Wilks testi ile değerlendirildi. Verileri değerlendirmek için tanımlayıcı istatistikler (sayı, yüzde, ortalama, standart sapma ve medyan), Tek Yönlü ANOVA testi, bağımsız örneklem $\mathrm{t}$ testi, Spearman korelasyon testleri ve çoklu regresyon analizi kullanıldı. Korelasyon kat sayısının $.00-.25$ arasında olması "çok zayıf", .26-.49 arasında olması "zayıf", .50-.69 arasında olması "orta", .70-.89 arasında olması "yüksek" ve $.90-1.00$ arasında olması "çok yüksek" düzeyde bir ilişki olarak tanımlandı. Sonuçlar $\% 95$ güven aralığında, $\mathrm{p}<.05$ anlamlılık düzeyinde değerlendirildi.

\section{Araştırmanın Etik Yönü}

Sosyal ve Beşeri Bilimler Araştırmaları Etik Kurulu'ndan 14/02/2019 tarih ve 35980450-663.05 sayı ile etik kurulu onayı alınmıştır. Örnekleme alınan kadınlardan bilgilendirilmiş olur formu ile yazılı onam alınmıştır. Çalışmada kullanılan ölçekler için yazarlardan e-posta ile kullanım izni alınmıştır. Ayrıca çalışmada, araştırma ve yayın etiğine uyulmuştur.

\section{Bulgular}

Çalışmaya katılan 300 katılımcının yaş ortalamas $29.75 \pm 0.48$ 'di. Katılımcıların \%37.4'ü 18-24 yaş aralığında ve $\% 50.3$ 'ü evliydi. \%75.6'sı kentte doğmuş ve \%78.6's1 en uzun süre yaşadığı kentte yaşamıştı. Katılımcıların $\% 60.3$ 'ünün eğitim durumu üniversite ve üzeri, $\% 56.7$ 'si çalışıyor ve $\% 55.3$ 'ünün geliri giderine eşitti. Katılımcıların $\% 47$ 'si en az bir kez gebelik deneyimlemiş, \%44'ü doğum yapmış ve \%46.9'u doğumunu özel bir hastanede gerçekleştirmişti. Katılımcıların \%17.3'ünün olumsuz doğum deneyimi varken, \%77'si başkalarından olumsuz doğum hikâyeleri dinlemişti (Tablo 1). 
Tablo 1. Katılımcıların Tanımlayıcı Özellikleri $(n=300)$

\begin{tabular}{|c|c|c|c|c|c|c|}
\hline \multirow[t]{2}{*}{ Değişkenler } & \multirow[t]{2}{*}{$\mathrm{N}$} & \multirow[t]{2}{*}{$\%$} & \multicolumn{3}{|c|}{ Cervantes Kişilik Ölçeği } & \multirow{2}{*}{$\begin{array}{l}\text { Travmatik } \\
\text { Doğum Alg1s1 } \\
\text { Ölçeği }\end{array}$} \\
\hline & & & $\begin{array}{l}\text { Dişa/içe } \\
\text { dönük } \\
\text { olma }\end{array}$ & Duygusal denge & $\begin{array}{l}\text { Tutarlı/tutarsiz } \\
\text { olma }\end{array}$ & \\
\hline $\begin{array}{r}\text { Yaş } 18-24 \\
25-34 \\
35-44 \\
>45\end{array}$ & $\begin{array}{l}112 \\
109 \\
52 \\
27\end{array}$ & $\begin{array}{l}37.4 \\
36.3 \\
17.3 \\
9.0\end{array}$ & $\begin{array}{l}17.29 \pm 2.96 \\
17.02 \pm 4.05 \\
17.15 \pm 3.64 \\
16.15 \pm 2.98 \\
F=0.777 \\
p=.508\end{array}$ & $\begin{array}{l}17.77 \pm 5.08 \\
16.90 \pm 5.97 \\
17.15 \pm 5.82 \\
16.89 \pm 5.57 \\
F=0.517 \\
p=.517\end{array}$ & $\begin{array}{l}16.70 \pm 4.24 \\
17.20 \pm 4.27 \\
16.96 \pm 4.91 \\
17.48 \pm 3.91 \\
F=0.361 \\
p=.781\end{array}$ & $\begin{array}{l}68.67 \pm 28.17 \\
64.90 \pm 33.21 \\
58.76 \pm 32.49 \\
57.33 \pm 34.05 \\
F=1.716 \\
p=.164\end{array}$ \\
\hline $\begin{array}{l}\text { Medeni durum } \\
\text { Evli } \\
\text { Bekar }\end{array}$ & $\begin{array}{l}151 \\
149\end{array}$ & $\begin{array}{l}50.3 \\
49.7\end{array}$ & $\begin{array}{l}16.74 \pm 3.91 \\
17.40 \pm 3.02 \\
t=-1.637 \\
p=.013\end{array}$ & $\begin{array}{l}17.21 \pm 5.74 \\
17.33 \pm 5.28 \\
t=-0.194 \\
p=.846\end{array}$ & $\begin{array}{l}16.98 \pm 4.70 \\
17.01 \pm 3.94 \\
t=-0.053 \\
p=.958\end{array}$ & $\begin{array}{l}62.88 \pm 34.65 \\
66.28 \pm 27.95 \\
t=-0.935 \\
p=.350\end{array}$ \\
\hline $\begin{array}{l}\text { Doğum yeri } \\
\text { Kentsel bölge } \\
\text { Kirsal bölge }\end{array}$ & $\begin{array}{l}227 \\
73\end{array}$ & $\begin{array}{l}75.6 \\
24.4\end{array}$ & $\begin{array}{l}16.99 \pm 3.45 \\
17.28 \pm 3.67 \\
t=-0.629 \\
p=.530\end{array}$ & $\begin{array}{l}17.39 \pm 5.59 \\
16.93 \pm 5.30 \\
t=0.647 \\
p=.518\end{array}$ & $\begin{array}{l}16.85 \pm 4.45 \\
17.38 \pm 3.99 \\
t=-0.933 \\
p=.352\end{array}$ & $\begin{array}{l}65.00 \pm 30.96 \\
63.38 \pm 33.02 \\
t=0.932 \\
p=.696\end{array}$ \\
\hline $\begin{array}{l}\text { Eğitim durumu } \\
\text { İlköğretim } \\
\text { Orta öğretim } \\
\text { Lise } \\
\text { Üniversite ve üzeri }\end{array}$ & $\begin{array}{l}38 \\
23 \\
58 \\
181\end{array}$ & $\begin{array}{l}12.7 \\
7.7 \\
19.3 \\
60.3\end{array}$ & $\begin{array}{l}15.00 \pm 5.13 \\
17.52 \pm 4.30 \\
17.00 \pm 3.58 \\
17.09 \pm 3.04 \\
F=0.991 \\
p=.397\end{array}$ & $\begin{array}{l}21.29 \pm 5.64 \\
18.16 \pm 6.63 \\
17.80 \pm 5.97 \\
16.72 \pm 5.00 \\
F=2.399 \\
p=.068\end{array}$ & $\begin{array}{l}15.00 \pm 6.42 \\
17.29 \pm 5.22 \\
16.80 \pm 4.69 \\
17.11 \pm 3.91 \\
F=0.639 \\
p=.590\end{array}$ & $\begin{array}{l}69.00 \pm 36.94 \\
67.12 \pm 31.34 \\
62.88 \pm 35.06 \\
64.71 \pm 29.79 \\
F=0.191 \\
p=.902\end{array}$ \\
\hline $\begin{array}{l}\text { Çalışma durumu } \\
\text { Çalışıyor } \\
\text { Çalışmıyor }\end{array}$ & $\begin{array}{l}170 \\
130\end{array}$ & $\begin{array}{l}56.7 \\
43.3\end{array}$ & $\begin{array}{l}16.96 \pm 3.15 \\
17.19 \pm 3.94 \\
t=-0.556 \\
p=.579\end{array}$ & $\begin{array}{l}16.60 \pm 5.39 \\
18.14 \pm 5.55 \\
t=-2.406 \\
p=.017 *\end{array}$ & $\begin{array}{l}17.11 \pm 4.16 \\
16.84 \pm 4.96 \\
t=0.592 \\
p=.537\end{array}$ & $\begin{array}{l}63.26 \pm 30.85 \\
66.27 \pm 32.32 \\
t=-0.821 \\
p=.412\end{array}$ \\
\hline $\begin{array}{l}\text { Gebelik yaşama } \\
\text { durumu } \\
\text { Evet } \\
\text { Hayır }\end{array}$ & $\begin{array}{l}141 \\
159\end{array}$ & $\begin{array}{l}47 \\
53\end{array}$ & $\begin{array}{l}16.72 \pm 3.88 \\
17.36 \pm 3.12 \\
t=-1.583 \\
p=.114\end{array}$ & $\begin{array}{l}17.38 \pm 5.83 \\
17.17 \pm 5.21 \\
t=0.323 \\
p=.747\end{array}$ & $\begin{array}{l}16.85 \pm 4.71 \\
17.13 \pm 3.97 \\
t=-0.554 \\
p=.580\end{array}$ & $\begin{array}{l}62.28 \pm 33.62 \\
66.59 \pm 29.41 \\
t=-1.176 \\
p=.241\end{array}$ \\
\hline $\begin{array}{l}\text { Doğum yapma } \\
\text { Evet } \\
\text { Hayır }\end{array}$ & $\begin{array}{l}132 \\
168\end{array}$ & $\begin{array}{l}44 \\
56\end{array}$ & $\begin{array}{l}16.77 \pm 3.83 \\
17.29 \pm 3.22 \\
t=-1.272 \\
p=.204\end{array}$ & $\begin{array}{l}17.34 \pm 5.90 \\
17.21 \pm 5.19 \\
t=0.207 \\
p=.207\end{array}$ & $\begin{array}{l}16.95 \pm 4.75 \\
17.03 \pm 3.99 \\
t=-0.157 \\
p=.875\end{array}$ & $\begin{array}{l}62.18 \pm 33.62 \\
64.44 \pm 29.65 \\
t=-1.144 \\
p=.254\end{array}$ \\
\hline $\begin{array}{l}\text { Doğum yapılan yer } \\
\text { Kamu hastanesi } \\
\text { Özel hastane } \\
\text { Ev }\end{array}$ & $\begin{array}{l}60 \\
62 \\
10\end{array}$ & $\begin{array}{l}45.4 \\
46.9 \\
7.7\end{array}$ & $\begin{array}{l}18.00 \pm 4.00 \\
16.00 \pm 3.00 \\
16.00 \pm 3.00 \\
F=4.326 \\
p=.115\end{array}$ & $\begin{array}{l}17.00 \pm 5.00 \\
17.00 \pm 6.00 \\
19.00 \pm 7.00 \\
F=5.604 \\
p=.061\end{array}$ & $\begin{array}{l}17.79 \pm 4.97 \\
17.03 \pm 4.37 \\
15.75 \pm 5.18 \\
F=3.227 \\
p=.199\end{array}$ & $\begin{array}{l}56.55 \pm 32.83 \\
61.97 \pm 33.89 \\
72.18 \pm 33.36 \\
F=3.011 \\
p=.222\end{array}$ \\
\hline $\begin{array}{l}\text { Olumsuz doğum deneyimi } \\
\text { Evet } \\
\text { Hayir }\end{array}$ & $\begin{array}{l} \\
52 \\
248\end{array}$ & $\begin{array}{l}17.3 \\
82.7\end{array}$ & $\begin{array}{l}15.85 \pm 3.76 \\
17.37 \pm 3.78 \\
t=-2.269 \\
p=.025^{*}\end{array}$ & $\begin{array}{l}18.35 \pm 5.52 \\
16.71 \pm 6.02 \\
t=1.583 \\
p=.116\end{array}$ & $\begin{array}{l}16.13 \pm 4.06 \\
17.57 \pm 5.07 \\
t=-1.723 \\
p=.087\end{array}$ & $\begin{array}{l}70.36 \pm 35.50 \\
57.40 \pm 31.41 \\
t=2.212 \\
p=.029^{*}\end{array}$ \\
\hline $\begin{array}{l}\text { Olumsuz doğum hikâyesi } \\
\text { duyma } \\
\text { Evet } \\
\text { Hayır }\end{array}$ & $\begin{array}{l}213 \\
87\end{array}$ & $\begin{array}{l}77 \\
23\end{array}$ & $\begin{array}{l}17.05 \pm 3.35 \\
17.10 \pm 3.87 \\
t=-0.126 \\
p=.900\end{array}$ & $\begin{array}{l}17.70 \pm 5.40 \\
16.20 \pm 5.64 \\
t=2.165 \\
p=.031^{*}\end{array}$ & $\begin{array}{l}16.72 \pm 4.28 \\
17.67 \pm 4.41 \\
t=-1.737 \\
p=.083\end{array}$ & $\begin{array}{l}67.62 \pm 30.61 \\
57.09 \pm 32.50 \\
t=2.656 \\
p=.008^{*}\end{array}$ \\
\hline
\end{tabular}


Sosyodemografik özellikler ve kişilik özellikleri karşılaştırıldığında; bekar katılımcıların evlilere göre daha içe dönük kişilik özelliğinde olduğu belirlendi $(\mathrm{t}=-1.637 ; \mathrm{p}=.013)$. Çalışmayan katılımcılar çalışanlara göre duygusal açıdan daha dengesizdi $(\mathrm{t}=-2.406 ; \mathrm{p}=.017)$. Geliri giderinden az olan katılımcıların geliri giderinden fazla olanlara göre duygusal açıdan daha dengesiz $(F=3.141 ; p=.045)$ ve tutarsız olduğu belirlendi $(F=3.975 ; p=.020)$. Olumsuz doğum deneyimi olduğunu ifade eden kadınlar diğerlerine göre daha dışa dönük kişilik özelliğine sahipti $(\mathrm{t}=-2.269 ; \mathrm{p}$ $=.025)$. Korkutucu doğum hikâyesi duymuş olan kadınların, duymamış olanlara göre duygusal açıdan daha dengesiz olduğu belirlendi $(\mathrm{t}=2.165 ; \mathrm{p}=.031)$. Sosyodemografik özellikler ve travmatik doğum algısı ilişkine bakıldığında; geliri giderinden az olan katılımcıların travmatik doğum algısı en yüksekken, geliri giderinden fazla olan katılımcıların travmatik doğum algısı en düşüktü $(F=5.377 ; p=.005)$. Olumsuz doğum deneyimi olduğunu ifade eden $(t=2.212 ; p$ $=.029)$ ve çevrelerinden korkutucu doğum hikâyesi dinleyen katılımcıların doğum olayını daha travmatik bir durum olarak algıladıkları belirlendi $(\mathrm{t}=2.656 ; \mathrm{p}=.008)$ (Tablo 1). Çalışmada travmatik doğum algısı ölçeği toplam puanı $64.57 \pm 31.48(0,130)$ idi. Cervantes Kişilik Ölçeği alt boyutlarından dışa/içe dönük olma alt boyut puanı $17.06 \pm 3.51$ (0-28), duygusal denge $17.27 \pm 5.51$ (1-33), tutarlı/tutarsiz olma $17.00 \pm 4.33$ (5-30) idi (Tablo 2).

Tablo 2. Katılımcıların Travmatik Doğum Algı Ölçeği Toplam Puanı ve Cervantes Kişilik Ölçeği Alt Ölçek Puanlart

\begin{tabular}{lcc}
\hline Ölçek puanı & $\mathrm{X} \pm \mathrm{SD}$ & Min-Max \\
\hline Travmatik Doğum Algı Ölçeği toplam puanı & $64.57 \pm 31.48$ & $0-130$ \\
\hline Cervantes Kişilik Ölçeği alt ölçek puanları & & $0-28$ \\
Dişa/içe dönük olma & $17.06 \pm 3.51$ & $1-33$ \\
Duygusal denge & $17.27 \pm 5.51$ & $5-30$ \\
Tutarlı/tutarsı olma & $17.00 \pm 4.33$ & \\
\hline
\end{tabular}

Çalışmada kişilik özellikleri ve travmatik doğum algısı ilişkisi incelendiğinde; kişilik ölçeği alt boyutlarından duygusal denge alt boyutu ile tutarlı/tutarsız olma alt boyutu arasında istatiksel açıdan pozitif yönde zayıf derecede anlamlı bir ilişki olduğu belirlendi $(r=.37 ; \mathrm{p}=.000)$. Travmatik doğum algısı ile içe/dışa dönüklük alt boyutu arasında pozitif yönde çok zayıf derecede $(\mathrm{r}=.19 ; \mathrm{p}=.001)$, travmatik doğum algısı ile duygusal denge alt boyutu arasında negatif yönde orta derecede $(\mathrm{r}=-.57 ; \mathrm{p}=.000)$ ve travmatik doğum algısı ile tutarlılık/tutarsızlık alt boyutu arasında negatif yönde zayıf derecede anlamlı bir ilişki belirlendi $(r=-.29 ; \mathrm{p}=.000)$ (Tablo 3).

Tablo 3. Travmatik Doğum Algısı Ölçeği Toplam Puanı ile Cervantes Kişilik Ölçeği Alt Ölçek Puanları Arasındaki İlişki

\begin{tabular}{|c|c|c|c|c|c|}
\hline & & $\begin{array}{l}\text { Dışa/içe dönük } \\
\text { olma }\end{array}$ & $\begin{array}{l}\text { Duygusal } \\
\text { denge }\end{array}$ & $\begin{array}{l}\text { Tutarl1/tutarsiz } \\
\text { olma }\end{array}$ & $\begin{array}{l}\text { Travmatik } \\
\text { Doğum Alg1 } \\
\text { Ölçeği }\end{array}$ \\
\hline \multirow[t]{2}{*}{ Dışa/içe dönük olma } & $r$ & 1.00 & -.03 & -.07 & .19 \\
\hline & $p$ & - & .514 & .214 & $.001 *$ \\
\hline \multirow[t]{2}{*}{ Duygusal denge } & $r$ & - & 1.00 & .37 & -.57 \\
\hline & $p$ & - & - & $.000 *$ & $.000 *$ \\
\hline \multirow[t]{2}{*}{ Tutarl1/tutarsız olma } & $r$ & - & - & 1.00 & -.29 \\
\hline & $p$ & - & - & - & $.000 *$ \\
\hline \multirow[t]{2}{*}{ Travmatik Doğum Alg1 Ölçeği } & $r$ & - & - & - & 1.00 \\
\hline & $p$ & - & - & - & - \\
\hline
\end{tabular}

*Spearman korelasyon testi *p<.01

Kadınlarda kişilik özelliklerinin travmatik doğum algısına etkisi Tablo 4’te gösterildi. CervantesKişilik Ölçeği alt boyutları ile travmatik doğum algısı arasındaki neden sonuç ilişkisini belirlemek üzereyapılan çoklu regresyon analizi, istatiksel açıdan anlamlı bulundu $(F=17.265 ; p=.000)$. Travmatik doğumalgısı düzeyindeki toplam \%38.6 oranındaki değişim “duygusal denge” alt boyutu tarafından açıklanmaktaydı. $\left(R^{2}=0.386\right)$. Bu analize göre CKÖ alt boyutlarından "duygusal denge" alt boyutundaki toplam \%38.6'lık değişim, travmatik doğum algısı düzeyini artırmada etkili bulundu $(\beta=.333 ; p=.000)$. 
Tablo 4. Travmatik Doğum Algısı Ölçeği Toplam Puanı ile Cervantes Kişilik Ölçeği Alt Ölçek Puanları Arasındaki ilişski

\begin{tabular}{|c|c|c|c|c|c|c|c|c|}
\hline $\begin{array}{l}\text { Bağımlı } \\
\text { değişken }\end{array}$ & $\begin{array}{l}\text { Bağımsız } \\
\text { değişken }\end{array}$ & $\beta$ & $t$ & $P$ & $F$ & Model $(p)$ & $R 2$ & $\begin{array}{l}\text { Durbin- } \\
\text { Watson }\end{array}$ \\
\hline \multirow{4}{*}{$\begin{array}{c}\text { Travmatik } \\
\text { doğum } \\
\text { algısı }\end{array}$} & Sabit & 45.876 & 3.152 & .002 & \multirow{4}{*}{17.265} & \multirow{4}{*}{.000} & \multirow{4}{*}{.386} & \multirow{4}{*}{2.013} \\
\hline & $\begin{array}{c}\text { Dişa/içe } \\
\text { dönük olma }\end{array}$ & -.034 & -.614 & .540 & & & & \\
\hline & $\begin{array}{c}\text { Duygusal } \\
\text { denge }\end{array}$ & .333 & 4.890 & .000 & & & & \\
\hline & $\begin{array}{c}\text { Tutarlı/tutarsiz } \\
\text { olma }\end{array}$ & -.072 & -1.017 & .310 & & & & \\
\hline
\end{tabular}

\section{Tartışma}

Kadınların doğuma ilişkin algıları ve doğum eylemine yükledikleri anlam kişiden kişiye farklılık göstermektedir (19). Bu sebeple literatürde travmatik doğum deneyimi prevalansı konusunda bir netlik bulunmamaktadır. Travmatik doğum deneyimi Amerika'da \%37, İran'da \%37, İsveç’te \%7, Hollanda'da \%16 ve Norveç'te \%21.1 oranında bildirilmiştir $(20,21)$. Travmatik doğum deneyimi prevalansının yüksek olduğu çalı̧malarda doğumun daha çok jinekolojik bir prosedür, ağrılı ve tehlikeli bir duruma yol açabilecek bir olay olarak değerlendirildiği belirlenmiştir. Buna karşılık, doğumun normal bir süreç olarak kabul edildiği İsveç ve Hollanda gibi ülkelerde kadınların yalnızca yarısından azına doğum sırasında rutin olarak oksitosin uygulandığı ve sadece lüzum halinde epizyotomi yapıldığı bildirilmektedir (22). Bazı ülkelerde doğum sırasında oksitosin kullanmak ve epizyotomi yapmak rutin protokollerdendir. Doğum sürecini hızlandırmak amacıyla oksitosinin rutin kullanımı ve kadınların rızası olmadan epizyotomi yapılması obstetrik şiddet olarak kabul edilmekte ve doğumun travmatik bir olay olarak algılanmasında temel etkenlerdendir (23). İran'da yapılan bir çalışmada postpartum birinci aydaki kadınların TDAÖ puan ortalaması $63.45 \pm 28.11$ (min: 0; max: 130) bulunmuştur (21). Türkiye'de yapılan çalışmalardan; Aktaş'ın (2018) gebeleri dâhil ettiği çalışmasında TDAÖ ölçek puan ortalaması $70.57 \pm 21.89$ (min: 0; max: 130) ve kadınların \%23.6 yüksek düzeyde travmatik doğum algısı yaşadığı bildirilmektedir. Başka bir çalışmada kadınların \%80.4'ünün doğum eylemini güzel, mutluluk verici bir deneyim olarak ifade ettiği, \%19.6'sının ise zor ve ağrılı buldukları bildirilmiştir (24). Bu çalı̧̧mada da travmatik doğum algısı ölçeği puan ortalaması $64.57 \pm 31.48$ (min: 0; max: 130) bulunmuştur. Çalışmalarda travmatik doğum algısı sonuçlarının birbirinden farklı olmasında çalışmanın yapıldığı coğrafi bölgeye özgü doğumda yapılan uygulamalardan, kültürel farklılıklardan, katılımcıların sosyodemografik ve obstetrik öykülerindeki farklılıklardan ve sorgulama formlarındaki çeşitlilikten kaynaklandığı düşünülmektedir.

Kadınların geçmişte yaşadıkları olumsuz doğum deneyimleri veya yaşadıkları kültürün doğum eylemine bakış açısı, travmatik doğum deneyimlerini etkileyebilmektedir (25). İran'da yapılan bir çalışmada kültür kaynaklı doğum korkusunun travmatik doğum deneyimi olasılığını 3.47 kat artırdığı bulunmuştur. Norveç'te yapılan bir çalışmada doğum korkusu olan kadınlarda travmatik doğum deneyimi prevalansının diğerlerine göre beş kat daha fazla olduğunu bildirilmiştir (21). Bu çalışmada da kadınların \%17.3'ünün olumsuz doğum deneyimi varken, \%77'si başkalarından olumsuz doğum hikâyeleri dinlediği ve hem olumsuz doğum deneyimi olanlarda hem de başkalarından olumsuz doğum hikâyeleri dinleyen kadınlarda travmatik doğum algısının diğerlerine göre daha yüksek olduğu bulunmuştur. Aile büyüklerinin anlattı̆̆ travmatik doğum öykülerinin ve çevreden duyulan olumsuz doğum hikayelerinin kadınların bilinç altına işleyerek doğum korkusunun oluşmasında hazırlayıcı rol oynadığı belirtilmektedir (26). Çevresinden doğumla ilgili olumsuz deneyimler dinleyen kadınlarda meydana gelen şiddetli doğum korkusu, gebelikte standart bakım almayı ve profesyonel destek almada isteklilik durumunu etkilemektedir. Sonuç olarak kadınlar doğum eylemiyle ilgili bilgi yetersizliği yaşayabilmekte ve travmatik doğum deneyimleyebilmektedir (27).

Literatürde sosyoekonomik açıdan dezavantajlı kadınlarda travmatik doğum deneyimi prevalansının daha yüksek olduğuna bildirilmiştir. İsveç’te yapılan bir çalışmada, gelir seviyesi düşük gebe kadınların diğerlerine göre normal doğum yapmaktan daha çok korktukları bulunmuştur. Başka çalışmada sağlık sigortası olmayan ve ekonomik durumu yetersiz olan kadınlarda travmatik doğum deneyimi prevalansının yüksek olduğu bulunmuştur (21). Türkiye'de yapılan çalışmalarda da düşük gelirli kadınların travmatik doğum algısı puanın yüksek gelir düzeyindeki kadınlara göre daha yüksek olduğu bulunmuştur (28). Bu çalışmada da geliri giderinden az olan katılımcıların travmatik doğum algısı en yüksekken, geliri giderinden fazla olan katılımcıların travmatik doğum algısının en düşük olduğu bulunmuştur. Başka bir çalışmada ise sosyodemografik özellikler ile travmatik doğuma bağlı postpartum travma sonrası stress yaşama arasında herhangi bir ilişki bulunamamıştır (29). Travmatik doğum algısı için gelir durumunun tek başına etkili faktör olmadığı düşünülmektedir. Aynı zamanda doğumun gerçekleştirildiği yer, gerekli bilgiye ulaşmada yetersizlikler ve sosyal destek eksikliği gibi olumsuz durumlar da doğumun travmatik bir olay olarak algılanmasına neden olabilmektedir (2).

Travmatik doğum algısını etkileyen faktörlerden biri de kadının kişilik özellikleridir. Literatürde farklı örneklem gruplarında CKÖ kullanılmıştır. Menopozal dönemdeki kadınlarla yapılan çalışmada dışa/içe dönük olma alt boyut puanı $12.69 \pm 6.46$, duygusal denge alt boyut puanı $14.35 \pm 4.97$ ve tutarlıl1k/tutarsızlık alt boyut puanı $20.28 \pm$ 5.08 bulunmuştur (30). Üniversite öğrencileriyle yapılan çalışmada CKÖ alt boyut puan ortalamaları dışa dönüklük/içe dönüklük, duygusal denge ve tutarlılık/tutarsızlı için sırasıyla $14.50 \pm 5.24,19.21 \pm 5.79$ ve $12.35 \pm 4.80$ bulunmuş̧ur (31). Premenstrual şikâyetleri olan üniversite öğrencileriyle yapılan çalışmada CKÖ puan ortalamaları; dışa/içe dönük 
olma $13.18 \pm 5.79$, duygusal denge $18.19 \pm 6.52$, tutarlı/tutarsız olma $12.23 \pm 5.21$ olarak belirlenmiştir (32). Başka çalışmada gebe kadınların CKÖ puan ortalamaları; dışa/içe dönük olma $8.62 \pm 4.02$, duygusal denge $8.55 \pm 2.79$ ve tutarlı/tutarsız olma $13.51 \pm 4.40$ olarak belirlemişlerdir (33). Çıtak (2020) çalışmasında dışa/içe dönük olma puan ortalamasının $13.07 \pm 5.60$, duygusal denge puan ortalamasının $18.35 \pm 6.19$ ve tutarlı/tutarsız olma puan ortalamasının $19.71 \pm 5.30$ olduğunu saptanmıştır. Bu çalışmada da literatüre benzer olarak CKÖ alt boyutlarından dışa/içe dönük olma alt boyut puanı $17.06 \pm 3.51$, duygusal denge $17.27 \pm 5.51$, tutarl1/tutarsı olma $17.00 \pm 4.33$ bulunmuştur. Bir çalışmada geliri giderinden fazla olan kadınların duygusal açıdan daha dengeli ve tutarlı oldukları belirlenmiştir (31). Başka çalışmada çalışan kadınların çalışmayan kadınlara göre daha dışa dönük kişilik yapısında oldukları belirlenmiştir (34). Bir başka çalışmada ise çalışan ve çalışmayan katılımcılarda duygusal denge alt boyutunda istatiksel açıdan anlamlı bir fark bulunmamıştır (30). Gebelerle yapılan bir çalışmada da çalışma durumunun ve ekonomik durumun kişilik özelliklerini etkilemediği bulunmuştur. Bu çalışmada çalışmayan katılımcıların çalışanlara göre duygusal açıdan daha dengesiz olduğu belirlenmiştir. Aynı zamanda geliri giderinden az olan katılımcıların geliri giderinden fazla olanlara göre duygusal açıdan daha dengesiz ve tutarsız olduğu bulunmuştur. Bir çalışmada duygusal açıdan dengeli katılımcıların daha dişa dönük olduğu bulunmuştur (34). Ryding ve arkadaşlarının 2007 yılında yapmış olduğu bir çalışmada ise duygusal açıdan dengeli katılımcıların daha tutarlı bir kişilik yapısında olduğu belirlenmiştir. Çalışmada aynı zamanda travmatik doğum algısı yüksek katılımcıların daha dışa dönük kişilik yapısında oldukları belirlenmiştir. İçe dönük kişilik özelliğine sahip bireyler, diğer insanlarla iletişime geçmekte veya var olan iletişimi sürdürmekte zorluk çekebilirler ve iş birliğine genellikle kapalıdırlar. Duygusal açıdan dengesiz kişilik özelliği sahip bireyler endişeli, öfkeli, içine kapanık, depresyona yatkın, kaygılı, gergin, güvensiz, düşük özgüvenli ve kendine güvenmeyen kişilik özelliğine sahip olabilmektedir (34). Bu sonuçlara göre duygusal açıdan dengeli olmanın bireyin dışa/içe dönük ve tutarlı/tutarsız olma durumunu etkileyebileceği düşünülmektedir. Bu çalışmada da dışa dönük kişilik özelliğine sahip kadınların travmatik doğum algılarını ifade etmede daha rahat olduklarından, travmatik doğum algısı puanlarının diğerlerine göre yüksek olduğu düşünülmektedir.

Duygusal olarak dengeli olan bireylerin yaşam olayları karşısında daha dengeli olup stres durumlarını daha iyi yönettikleri bilinmektedir (35). Yüksek doğum korkusu ise travmatik doğum algısını arttırıcı etkiye sahip olabilmektedir. Saisto ve arkadaşlarının 2001 yılında yaptığı çalışmada doğum korkusu ile CKÖ dışa/içe dönüklük alt boyutu arasında negatif yönde ilişki olduğu belirlenmiştir (36). Spice ve arkadaşlarının 2009 yılındaki çalışmasında ise gebelerin dışa dönük olma kişilik özelliğinin, doğum korkusunu azaltıcı bir etkiye sahip olduğu belirtilmiştir. Başka bir çalışmada da dışa dönük kişilik özelliğine sahip kadınların çevreleriyle daha fazla iletişim kurmalarının ve gebelikle ilgili sorunlarını daha rahat ifade etmelerinin, doğum korkularını azaltıcı bir etkisi olduğu bildirilmiştir (37). Finlandiya'da yapılan bir çalışmada kişilik özelliğinin, doğumla ilgili beklentileri etkileyebildiği bulunmuştur. Aynı çalışmada doğum korkusunun özgüven eksikliği olan, endişeli ve içine kapanmış kadınlarda daha yaygın olduğunu sonucuna ulaşılmıştır. Bir çalışmada ise yoğun korku yaşayan kadınların, doğumlarıyla ilgili daha olumsuz deneyimler yaşadıkları saptanmıştır (36). Başka çalışmada, gebelerin yaşadığı doğum korkusuyla sürekli anksiyete arasında istatiksel açıdan anlamlı bir ilişki bulunmuştur. Bir çalışmada ise doğum korkusu olanların daha dişa dönük, tutarsız ve duygusal açıdan daha dengesiz oldukları belirlenmiştir (34). Başka bir çalışmada da doğum korkusu olan kadınların duygusal açıdan daha dengesiz olduğu bildirilmiştir. Bu çalışmada da literatürle uyumlu olarak olumsuz doğum deneyimi olduğunu ifade eden kadınların diğerlerine göre daha dışa dönük olduğu belirlenmiştir. Aynı zamanda çalışmada korkutucu doğum hikâyesi duymuş olan kadınların, duymamış olanlara göre duygusal açıdan daha dengesiz olduğu bulunmuştur. Doğumun nasıl olacağının bilinmezliği, ilk gebelik oluşu, yoğun ve karmaşık duyguların görülmesi nedeniyle oluşabilen doğum korkusu kadınların daha dengesiz kişilik özelliği göstermesine neden olabilmektedir (31).

\section{Kisitlılıklar}

Veriler belirli bir tarih aralığında örneklem seçimine gidilmeden toplanmıştır. Bu sebeple araştırma sonuçları yalnızca bu çalışma için genellenebilir. Ankete verilen yanıtların güvenilirliği, çalışmaya katılan kadınların verdikleri bilgilerin doğruluğu ile sınırlıdır. Ayrıca çalışma verileri İstanbul'un kalabalık meydanlarında toplandığından bireyler araştırmaya katılım konusunda çekimser kalmışlar ve bu sebeple araştırmanın yürütüldüğü tarih aralığında hedeflenen örneklem sayısına ulaşılamamıştır. Katılımcılar travmatik doğum algısı konusunda görüşlerini bildirmek istemediklerinden istenen örneklem sayısına ulaşmakta zorluk yaşanmıştır.

\section{Sonuçların Uygulamada Kullanımı}

Çalışmadan elde edilen sonuçlar doğrultusunda travmatik doğum algısı yüksek olan kadınların erken dönemde belirlenip uygun hemşirelik girişimlerinin planlanması önerilebilir. Olumlu bir doğum deneyimi yaratmak için kadınlar doğum sırasında desteklenmeli, en az müdahaleyle intrapartum bakım verilmeli ve doğuma hazırlık yapılmalıdır. Travmatik doğum algısını etkileyen faktörlerden biri olan kişilik özelliklerinin belirlenmesi ve bakım sürecinde bu özelliklerin dikkate alınması önerilebilir. İçe dönük kişilikteki kadınlara daha fazla zaman tanınarak, kadınların doğuma yönelik duygu ve düşüncelerini rahat ifade etmeleri sağlanmalıdır. Sağlık profesyonelleri duygusal açıdan dengesiz özelliğe sahip kadınların aşırı tepkisellikleri ve duygusal tutarsızlıkları göz önünde bulundurularak danışmanlık vermeli ve girişimlerinde bunu dikkate almalıdır. Kişilik özelliklerinin etkisinin belirlenmesi amaçlı her kültürden bireyi içeren daha geniş örneklem grubuyla tanımlayıcı çalışmaların yapılması önerilebilir. Gelecek çalışmalarda kadınların doğum korkularının derecesi araştırılmalı ve gerekli danışmanlık hizmetleri planlanmalıdır. Ayrıca kadınlarda kişilik özellikleriyle başa çıkma yöntemlerinin geliştirilmesi çalışmaları yapılmalıdır. Bu kapsamda nonfarmakolojik yöntemlerden gevşeme ve nefes egzersizlerini içeren girişimsel çalışmalar planlanabilir. Bu araştırmanın kadınların kişilik özellikleri ile travmatik doğum algısı arasındaki ilişkiyi açıklayarak literatüre katkı sağlayacağı düşünülmektedir. Ayrıca, literatürde travmatik doğum algısına katkıda bulunduğu bildirilen parametrelerden kişilik özelliklerinin etkisi detaylı incelenmiştir. Bu sonuçlar doğrultusunda sağlık profesyonelleri, travmatik doğum algısı yüksek olan kadınların 
bakımlarını planlarken kişilik özelliklerini de dikkate alabilecektir.

\section{Bilgilendirme}

Yazarların araştırmaya katkı oranı beyanları şu şekildedir; Araştırma Fikri: BY, İS, NŞ; Çalışma Tasarımı: BY, İS, NŞ; Literatür Taraması: BY, İS; Veri Toplanması ve/veya İşlemesi: İS; İstatistiksel Analiz ve/veya Yorum: BY; Makale Yazımı: BY, İS, NŞ; Denetleme, Eleştirel İnceleme ve Son Kontrolün Yapılması: BY, NŞ. Araştırmanın bütçesi yazarlar tarafından karşılanmıştır ve araştırma için herhangi bir finansal destek alınmamıştır. Araştırmacılar arasında çıkar çatışması yoktur. Araştırma için Sosyal ve Beşeri Bilimler Araştırmaları Etik Kurulu'ndan 14/02/2019 tarih ve 35980450-663.05 sayı ile etik kurulu onayı alınmıştır. 


\section{Kaynaklar}

1. Namujju J, Muhindo R, Mselle LT, Waiswa P, Nankumbi J, Muwanguzi P. Childbirth experiences and their derived meaning: a qualitative study among postnatal mothers in Mbale regional referral hospital, Uganda. Reproductive Health. 2018;15(1):183-194.

2. Elmir R, Schmied V, Wilkes L, Jackson D. Women's perceptions and experiences of a traumatic birth: a metaethnography. Journal of Advanced Nursing. 2015;66:2142-2153.

3. Furuta M, Horsch A, Ng ES, Bick D, Spain D, Sin J. Effectiveness of trauma-focused psychological therapies for treating post-traumatic stress disorder symptoms in women following childbirth: a systematic review and meta-analysis. Frontiers in Psychiatry. 2018;9:591-608.

4. Karaman ÖE, Yıldız H. Doğum eylemi travay sürecinde hareket serbestliği: Nasıl? Ne sağlar? Kadın doğum hemşiresinin rolü nedir? Turkiye Klinikleri Journal of Nursing Sciences. 2018;10(1):78-87.

5. Beck CT. Middle range theory of traumatic childbirth: The ever-widening ripple effect. Global Qualitative Nursing Research. 2015;. 2015;2:1-13.

6. World Health Organization. Recommendations: Intrapartum care for a positive childbirth experience [online]. URL:https://www.who.int/reproductivehealth/publications/intrapartum-care- guidelines/en/ 11 Temmuz 2020

7. Yalnız Dilcen H, Genc R. The effects of psychoeducation on the traumatic perception of the birth phenomenon in women with substance-use disorders. Substance Use \& Misuse. 2019;1-9.

8. Taheri M, Takian A, Taghizadeh Z, Jafari N, Sarafraz, N. Creating a positive perception of childbirth experience: Systematic review and meta-analysis of prenatal and intrapartum interventions. Reproductive Health. 2018;15(1):7386.

9. Biaggi A, Conroy S, Pawlby S, Pariante CM. Identifying the women at risk of antenatal anxiety and depression: A systematic review. Journal of Affective Disorders. 2016;191:62-77.

10. Grekin R, O’Hara MW. Prevalence and risk factors of postpartum posttraumatic stress disorder: A meta-analsis. Clinical Psychology Review. 2014;34:389-401.

11. Walker AL, Gamble J, Creedy DK, Ellwood DA. Impact of traumatic birth on Australian obstetricians: A pilot feasibility study. Australian and New Zealand Journal of Obstetrics and Gynaecology. 2020;60(4):555-560.

12. Rondung E, Thomtén J, Sundin Ö. Psychological perspectives on fear of childbirth. J Anxiety Disord. 2016;44:80-91.

13. Date C, van der Veen, Silvia DM, van Dijk, Hannie C, Comijs, et al. The importance of personality and lifeevents in anxious depression: from trait to state anxiety, Aging \& Mental Health. 2017;21(11):1177-1183.

14. Mccrae RR, Costa Jr PT. Understanding persons: From Stern's personalistics to Five-Factor Theory. Personality and Individual Differences. 2020;109816.

15. Gönenç İM, Aker MN, Güven H, Moraloğlu Tekin Ö. The effect of the personality traits of pregnant women on the fear of childbirth. Perspectives in psychiatric care. 2020;56(2):347-354.

16. Türkiye İstatistik Kurumu (TÜİK). Adrese dayalı nüfus kayı sistemi. [online]. URL: https://data.tuik.gov.tr/Bulten/Index?p=Adrese-Dayal\%C4\%B1-N\%C3\%BCfus-Kay\%C4\%B1t- SistemiSonu\%C3\%A7lar\%C4\%B1-2019-33705\&dil=1 4 Ocak 2020

17. Bal M, Sahin N. Adaptation of cervantes personality scale into Turkish: Validity and reliability study. Journal of Nursing Education and Research. 2011;8(1):39-45.

18. Yalnız H, Canan F, Genç R, Kuloğlu MM. Development of the traumatic birth perception scale. Turkish Journal Of Medical Sciences. 2016;8(3):81-88.

19. Murphy H, Strong J. Just another ordinary bad birth? A narrative analysis of first time mothers' traumatic birth experiences. Health Care for Women International. 2018;39(6):619-643.

20. Ghanbari-Homayi S, Fardiazar Z, Meedya S, Mohammad-Alizadeh-Charandabi S, Asghari- Jafarabadi M, Mohammadi E, et al. Predictors of traumatic birth experience among a group of Iranian primipara women: A cross sectional study. BMC Pregnancy and Childbirth. 2019;19(1):182-191.

21. Henriksen L, Grimsrud E, Schei B, Lukasse M. Bidens study group: Factors related to a negative birth experience-a mixed methods study. Midwifery. 2017;51:33-39.

22. Bernitz S, Øian P, Rolland R, Sandvik L, Blix E. Oxytocin and dystocia as risk factors foradverse birth outcomes: a cohort of low-risk nulliparous women. Midwifery. 2014;30(3):364-370.

23. Jardim DMB, Modena CM. Obstetric violence in the daily routine of care and its characteristics. Revista Latinoamericana de Enfermagem. 2018;26:e3069.

24. Aktaş S. Multigravidas' perceptions of traumatic childbirth: Its relation to some factors, the effect of previous type of birth and experience. Medicine Sience. 2018;7(1):203-209.

25. Downe S, Finlayson K, Oladapo OT, Bonet M, Gülmezoglu AM. What matters to women during childbirth: A systematic qualitative review. PLoS One. 2018;13(4):e0194906.

26. Nilsson L, Thorsell T, Hertfelt Wahn E, Ekström A. Factors influencing positive birthexperiences of first-time mothers. Nursing Research and Practice. 2013;1-7.

27. Rouhe H, Salmela-Aro K, Toivanen R, Tokola M, Halmesmäki E, Ryding EL, et al. Group psychoeducation with relaxation for severe fear of childbirth improves maternal adjustment and childbirth experience-a randomised controlled trial. Journal of Psychosomatic Obstetrics \& Gynecology. 2015;36(1):1-9.

28. Lazzerini M, Mariani I, Semenzato C, Valente EP. Association between maternal satisfaction and other indicators of quality of care at childbirth: A cross-sectional study based on the WHO standards. BMJ Open. 2020;10(9):e037063.

29. Adewuya AO, Ologun YA, Ibigbami OS. Post-traumatic stress disorder after childbirth in Nigerian women: prevalence and risk factors. BJOG: An International Journal of Obstetrics and Gynaecology. 2019;284-288. 
30. Ergin IO, Yağmur Y. The correlation between menopausal complaints and personality traits. 2018;1-6.

31. Aydin Ozkan S, Kucukkelepce DS. Do university students' personality traits affect their attitudes towards gender roles? Perspectives in Psychiatric Care. 2019;55(4):562-569.

32. Ölçer Z, Bakır N, Aslan E. Üniversite öğrencilerinde kişilik özelliklerinin premenstrual şikâyetlere etkisi. Düzce Üniversitesi Sağlık Bilimleri Enstitüsü Dergisi. 2017;1(1):30-37.

33. Erdemoğlu Ç, Altıparmak S, Özşahin Z. The effect of personality traits of pregnants and their ways of coping with stress on the fear of childbirth. The Journal of Turkish Family Physician. 2019;10(3):130-139.

34. Murray L, O’Neill L. Neuroticism and extraversion mediate the relationship between having a sibling with developmental disabilities and anxiety and depression symptoms. Journal of Affective Disorders. 2019;243:232-240.

35. Dursun E, Kizılirmak A, Mucuk S. The relationship between personality characteristics and fear of childbirth: A descriptive study. Archives of Psychiatric Nursing. 2021;35(3):296-302.

36. Saisto T, Salmela-Aro K, Nurmi JE, Halmesmäki E. Psychosocial characteristics of women and their partners fearing vaginal childbirth. BJOG: An International Journal of Obstetrics and Gynaecology. 2001;108:492-498.

37. Spice K, Jones SL, Hadjistavropoulos HD, Kowalyk K, Stewart SH. Prenatal fear of childbirth and anxiety sensitivity. Journal of Psychosomatic Obstetrics \& Gynecology. 2009;30(3):168-174. 